\title{
Is export-led growth hypothesis still valid for sub-Saharan African countries? New evidence from panel data analysis
}

\author{
Nicholas M. Odhiambo
}

\author{
Macroeconomic Policy Analysis (MPA) Programme, Department of Economics, \\ University of South Africa, Pretoria, South Africa
}

\begin{abstract}
Purpose - This study examines the causal relationship between exports and economic growth in sub-Saharan African (SSA) countries during the period 1980 to 2017. The study also examines whether the causality between these two macroeconomic variables depends on the countries' stage of development as proxied by their per capita income.

Design/methodology/approach - The study uses a panel cointegration test and panel Granger-causality model to examine the link between exports and growth. The study also incorporates external debt as an intermittent variable in a bivariate setting between exports and economic growth, thereby creating a dynamic multivariate panel Granger-causality model.

Findings - Although the study found the existence of a long-run relationship between exports and economic growth, the study failed to find any export-led growth response in both low-income and middle-income countries. Instead, the study found evidence of a bidirectional causality and a neutrality response in middleincome and low-income countries, respectively. The study, therefore, concludes that the benefits of an exportled growth hypothesis may have been oversold, and that the strategy may not be desirable to some low-income developing countries.

Practical implications - These findings have important policy implications as they indicate that the causality between exports and economic growth in SSA countries varies with the countries' stage of development. Consistent with the contemporary literature, the study cautions low-income SSA countries against over-relying on an export-led growth strategy to achieve a sustained growth path as no causality between exports and economic growth has been found to exist in those countries. Instead, such countries should consider pursuing new growth strategies by building the domestic demand side of their economies alongside their export promotion strategies in order to expand the real sector of their economies. For middleincome countries, the study recommends that both export promotion strategies and pro-growth policies should be intensified as economic growth and exports have been found to reinforce each other in those countries.

Originality/value - Unlike the previous studies, the current study disaggregated the full sample of SSA countries into two subsets - one comprising of low-income countries and the other consisting of middle-income countries. In addition, the study uses a multivariate Granger-causality model in order to address the emissionof-variable bias. To our knowledge, this may be the first study of its kind in recent years to examine in detail the causal relationship between exports and economic growth in SSA countries using an ECM-based multivariate panel Granger-causality model.
\end{abstract}

Keywords Granger causality, Economic growth, Exports, Sub-Saharan Africa

Paper type Research paper

\section{Introduction}

The relationship between exports and economic growth has attracted numerous studies in recent decades. The thrust of the debate has been whether exports drive economic growth or

(C) Nicholas M. Odhiambo. Published in European Journal of Management and Business Economics. Published by Emerald Publishing Limited. This article is published under the Creative Commons Attribution (CCBY 4.0) licence. Anyone may reproduce, distribute, translate and create derivative works of this article (for both commercial and non-commercial purposes), subject to full attribution to the original publication and authors. The full terms of this licence may be seen at http://creativecommons. org/licences/by/4.0/legalcode

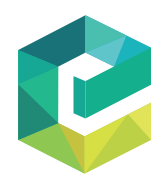

European Journal of Management and Business Economics Vol. 31 No. 1,2022
pp. $77-93$ Emerald Publishing Limited e-ISSN: 2444-8494 p-ISSN: $2444-8451$ DOI 10.1108/EJMBE-06-2020-0156 
EJMBE 31,1 whether it is the growth of the real sector that drives exports. While the former view is referred to as the export-led growth (ELG) hypothesis, the latter is popularly known as the growth-led export (GLE) hypothesis. According to the ELG hypothesis, real GDP growth does not only rely on the increase in the amounts of labour and capital, but also on the growth of exports through a multiplier effect. This makes export one of the engines of economic growth. Moreover, an increase in exports as a result of export-oriented policies can also indirectly stimulate economic growth through the efficient allocation of resources, greater capacity utilisation and exploitation of economies of scale (Awokuse, 2003). Apart from stimulating technological enhancement due to foreign market competition, exports also play a critical role in enabling investment and technological transfer, which accelerates the process of globalisation (see Keesing, 1967; Bhagwati and Srinivasan, 1975; Dervis, 1979) [1]. An increase in exports also provides foreign exchange, which can be used for importing capital goods and intermediate goods, thereby leading to higher capital formation, which, in turn, leads to higher economic growth (McKinnon, 1964; Balassa, 1978; Buffie, 1992). Indeed, the remarkable performance by a number of Asian countries can be attributed to the beneficial effects of exports on economic growth (see Salim and Hossain, 2011; Awokuse and Christopoulos, 2009; Lee and Huang, 2002; El-Sakka and Al-Mutairi, 2000) [2]. Although exports can significantly contribute to economic growth, some studies have argued that there is a danger in over-relying on exports to boost economic growth, especially in developing countries. This is mainly because the market for the exports of developing countries is limited by the capacity of industrialised countries. Hence, stagnation in demand in developed countries may lead to overinvestment and excess capacity in developing countries (see Blecker, 2002; 2003; Felipe, 2003). Moreover, some recent studies have argued that the benefits of an exportled growth hypothesis may have been oversold, and that the strategy may not be desirable to some low-income developing countries; hence, a new development paradigm is needed. According to Pillay (2011), there is a need for a shift towards a domestic demand-led growth strategy, while maintaining exports as countries still need exports to pay for their imported inputs and some finished goods that cannot be produced locally (see Pillay, 2011, p. 9).

As opposed to the ELG hypothesis, the GLE hypothesis postulates that an increase in economic growth could also lead to an increase in exports through a realisation of economies of scale and a reduction in the cost of production (see Bahmani-Oskooee, 2009). Previous studies have also argued that an increase in GDP is likely to lead to a corresponding increase in trade, unless an anti-bias trade is created by the growth-induced supply and the corresponding demand (Bhagwati, 1988). The GLE hypothesis has also been supported by the neoclassical trade theory. According to the neoclassical trade theory, economic growth, through its effects on the supply of the economy (factor endowments), may create more demand for exports within a country, thereby affording a country a strong export production base (Mahadevan, 2007).

Although a number of studies have been conducted on the relationship between exports and economic growth, especially since the 1960s, the majority of these studies have mainly been conducted on Asia and Latin America, thereby leaving many SSA countries with little or no coverage at all (see, for example, Ahmad et al., 2018; Ali and Li, 2018; Shakeel and Ahmed, 2020; Dinç and Gökmen, 2019; Kalaitzi and Chamberlain, 2020, among others). Even where such studies have been conducted, the findings on the causal relationship between exports and economic growth remains mixed at best and controversial at worst. In addition, some of these previous studies have fundamental methodological weaknesses. It is against this background that the current study aims to examine the causal relationship between exports and economic growth in 21 sub-Saharan African countries using a panel Granger-causality model. In order to address the omission-of-variable bias, which has been reported in some of the previous studies, the current study uses a multivariate panel Granger-causality model to examine this linkage. In order to examine whether the causality between exports and 
economic growth depends on the countries' stage of development as proxied by their per capita income, the study disaggregated the full sample of SSA countries into two subsets one comprising of low-income countries and the other consisting of middle-income countries.

To our knowledge, the studies that are closest to the current research are based on the work done by Ee (2016) and Ahmad and Kwan (1991). However, the current study differs fundamentally from these two studies in various ways. For example, Ee (2016) used fully modified OLS (FMOLS) and dynamic ordinary least square (DOLS) to test the export-led growth hypothesis, while the current study uses an ECM-based multivariate panel Grangercausality model to examine the short-run and long-run causality between exports and economic growth. In addition, in the current study, two panels of SSA countries are used, namely low-income and middle-income panels. Ahmad and Kwan (1991), on the other hand, used a bivariate Granger-causality model, while the current study uses a multivariate ECMbased Granger-causality model, which reduces the omission-of-variable bias and captures the short-run and long-run causal dynamics.

The rest of the paper is structured as follows. Section 2 reviews some of the empirical literature on the relationship between exports and economic growth in developing and developed countries. Section 3 deals with the methodology, empirical analysis and discussion of the results. Section 4 concludes the study.

\section{Literature review}

Previous studies on the relationship between exports and economic growth vary significantly between those that are in favour of the export-led growth (ELG) strategy and those that are in favour of growth-led export (GLE) strategy. Theoretically, the export-led growth (ELG) strategy hinges on whether a country should focus on export promotion or import substitution. In the main, the proponents of export-led growth theory support export promotion policy instead of import substitution policy. According to a comprehensive study by World Bank (1987), export-promotion strategy is the best strategy for less developing countries (LDCs) that intends to industrialise and transform their economies into more developed economies (see Tang et al., 2015). This view argues that growth could be achieved better through ELG strategies. A case in point is the growth rate that has been achieved by the Asian economies, such as Hong Kong, Singapore, South Korea, Taiwan, Malaysia and Thailand that were found to have been supported by the export promotions strategies. Over a period of 30 years, these countries were found to have doubled their standards of living every ten years (see Giles and Williams, 2000). According to the proponents of ELG theory, export growth leads to an increase in the demand for the country's output, which leads to an increase in real output. An increase in a country's exports may inter alia lead to an increase in the specialisation of export goods, which may, in turn, boost the country's productivity level and eventually leads to output growth (see Giles and Williams, 2000). In addition, the outward-oriented trade policy resulting from the ELG strategy may also give access to advanced technologies, learning by doing gains and better management practices, which may lead to further efficiency gains (see Giles and Williams, 2000; Hart, 1983; Ben-David and Loewy, 1998). Apart from the ELG, recent studies have shown that there is also a potential for growth-led export (GLE). Bhagwati (1988), for example, argues that an increase in GDP generally leads to a corresponding expansion of trade, unless the pattern of growth-induced supply and corresponding demand creates an anti-trade bias. Neoclassical trade theory also stresses the causality that runs from home-factor endowments and productivity to the supply of exports (see Findlay, 1984).

On the empirical front, there are a number of studies that have been conducted to examine the causal relationship between exports and economic growth in both developed and developing countries. However, the findings of such studies remain at best inconclusive and often contradictory. Broadly speaking, previous studies on this subject can be divided into 
EJMBE 31,1 four groups. The first group includes studies, whose findings are consistent with a unidirectional causal flow from exports to economic growth. These studies include, amongst other, studies such as Boame (1998) for the case of Ghana; El-Sakka and Al-Mutairi (2000) for Iraq, Morocco, Saudi Arabia and Syria; Fountas (2000) for Ireland; Awokuse (2003) for Canada; Shirazi and Manap (2005) for Pakistan; Siliverstovs and Herzer (2006) for Chile; Jordaan and Eita (2007) for Namibia; Narayan et al. (2007) for the case of Papua New Guinea in the short run and Fiji in the long run; Dash (2009) for India; Rangasamy (2009) for South Africa; Uddin et al. (2010) for Bhutan; Ramona et al. (2010) for Romania; Samad (2011) for Algeria; Saad (2012) for Lebanon; Tsaurai and Odhiambo (2012) for Zimbabwe; Dritsaki (2013) for Greece; Abdulkarim (2014) for Saudi Arabia; Bilas et al. (2015) for Croatia; Ee (2016) for the case of selected sub-Saharan African (SSA) countries; Ali and Li (2018) for China and Pakistan; Ahmad et al. (2018) for ASEAN5 economies; Dinç and Gökmen (2019) for the case of Brazil in the short run; Kalaitzi and Chamberlain (2020) for the case of the United Arab Emirates in the short run; Kim et al. (2019) for Myanmar; Shakeel and Ahmed (2020) for a panel of five South Asian countries in the long run.

Unlike the first group, the second group of studies supports a unidirectional causal flow from economic growth to exports. These include studies, such as Oxley (1993) for the case of Portugal; Ahmad and Harnhirun (1996) for the case of ASEAN Countries; Henriques and Sadorsky (1996) for Canada; Baharumshah and Rashid (1999) for Malaysia; El-Sakka and AlMutairi (2000) for the United Arab Emirates; Hatemi-J and Irandoust (2000) for the case of Denmark; Panas and Vamvoukas (2002) for the case of Greece in the long run; Shan and Tian (2002) for Shanghai; Reppas and Christopoulos (2005) for the case of 22 less developed Asian and African countries; Cetintas and Barisik (2009) for 13 transition economies; Abbas (2012) for Pakistan; Igbal et al. (2012) for Pakistan; Shihab et al. (2014) for Jordan; Bonga et al. (2015) for Zimbabwe; Gokmenoglu et al. (2015) for Costa Rica; Popovici and Călin (2016) for Romania; and more recently, Kalaitzi and Cleeve (2018) for the case of the UAE in the long run.

Apart from the first group and the second group of studies, there is a third (middle-ground) group, which posits that both exports and economic growth Granger-cause each other. In other words, this group argues that there is bidirectional causality between exports and economic growth. Studies whose findings are consistent within this view include studies, such as Kwan and Cotsomitis (1991) for the case of China during the period 1952-1985; Bahmani-Oskooee and Janardhanan (1993) for the case of LDCs; Shan and Sun (1998) for China; El-Sakka and Al-Mutairi (2000) for Algeria, Bahrain, Egypt, Jordan, Mauritania and Oman; Hatemi-J and Irandoust (2000) for the case of Finland, Norway and Sweden; Wernerheim (2000) for Canada; Abdulnasser (2002) for Japan; Awokuse (2005) for Korea; Shirazi and Manap (2005) for Bangladesh and Nepal; Jordaan and Eita (2009) for Botswana; Elbeydi et al. (2010) for Libya; Tsen (2010) for China; Rahmaddi and Ichihashi (2011) for Indonesia; Sallem and Sial (2015) for Pakistan; Sunde (2017) for South Africa; Guntukula (2018) for India; Kalaitzi and Cleeve (2018) for the case of the UAE in the short run; Dinç and Gökmen (2019) for Brazil in the long run; and more recently, Shakeel and Ahmed (2020) for a panel of five South Asian countries in the short run.

Despite the overwhelming causal relationship between exports and economic growth reported in the above-mentioned studies, there is the fourth group (i.e. neutrality group) whose empirical findings show that there is no formidable causal relationship between exports and economic growth and that any perceived relationship could be merely mechanical in nature. Although this view is somewhat unpopular, it is currently gaining traction in the empirical literature. Some of the studies whose findings are in one way or the other consistent with this view include those of Ahmad and Kwan (1991) for the case of 47 African Countries; Jin and Yu (1996) for the USA; Abdulnasser and Manucher (2000) for the case of Greece and Turkey; Ahmed et al. (2000) for the case of Bangladesh, Pakistan and Sri 
Lanka; El-Sakka and Al-Mutairi (2000) for Kuwait, Libya, Qatar, Sudan and Tunis; Shirazi and Manap (2005) for Sri Lanka and India; Tang (2006) for China; Tang (2006) for China; Shirazi and Manap (2005) for Sri Lanka and India; more recently, Kalaitzi and Chamberlain (2020) for the case of the United Arab Emirates in the long run.

Table 1 gives a summary of previous empirical findings on the causal relationship between exports and economic growth in both developed and developing countries, based on these four groups of studies.

Exports and economic growth in SSA

\section{Empirical analysis}

\subsection{Model specification - a trivariate Granger-causality model}

This study uses panel data and a trivariate Granger-causality model to examine the causal relationship between exports and economic growth in SSA countries. The use of this technique is deemed most suitable in this study because of the various advantages it renders. Firstly, a panel data technique has the ability to test more complicated behavioural models than a single cross-sectional or time-series data technique (see Hsiao, 2003). Secondly, panel data contains more degrees of freedom and more sample variability than cross-sectional or time-series data (Hsiao et al., 1995). Thirdly, panel data analysis generates more accurate predictions for individual outcomes by pooling the data rather than generating predictions of individual outcomes using the data on the individual in question (Hsiao et al., 1989, 1993) [3]. The Granger causality model adopted in this study is expressed as follows (see Odhiambo, 2015):

$$
\begin{aligned}
\Delta y / N_{i t}= & \alpha_{1 j}+\sum_{k=1}^{q} \beta_{11 i k} \Delta y / N_{i t-k}+\sum_{k=1}^{q} \beta_{12 i k} \Delta \mathrm{EXPT}_{i t-k}+\sum_{k=1}^{q} \beta_{13 i k} \Delta \mathrm{DEBT}_{i t-k} \\
& +\lambda_{1 i} E C T_{i t-1}+\varepsilon_{i t} \\
\Delta \mathrm{EXPT}_{i t}= & \alpha_{2 j}+\sum_{k=1}^{q} \beta_{21 i k} \Delta \mathrm{EXPT}_{i t-k}+\sum_{k=1}^{q} \beta_{22 i k} \Delta y / N_{i t-k}+\sum_{k=1}^{q} \beta_{23 i k} \Delta \mathrm{DEBT}_{i t-k} \\
& +\lambda_{2 i} \mathrm{ECT}_{i t-1}+\varepsilon_{i t} \\
\mathrm{DDEBT}_{i t}= & \alpha_{3 j}+\sum_{k=1}^{q} \beta_{31 i k} \Delta \mathrm{DEBT}_{i t-k}+\sum_{k=1}^{q} \beta_{32 i k} \Delta y / N_{i t-k}+\sum_{k=1}^{q} \beta_{33 i k} \Delta \mathrm{EXPT}_{i t-k} \\
& +\lambda_{3 i} \mathrm{ECT}_{i t-1}+\varepsilon_{i t}
\end{aligned}
$$

where:

$y / N \quad$ Real GDP per capita

EXPT Exports

DEBT External debt

$\Delta \quad$ First difference operator

ECT Error-correction term

$\varepsilon \quad$ White noise error term

$i \quad$ Individual country

$t \quad$ Time period

$q \quad$ Lag length 


\section{EJMBE 31,1}

82

\begin{tabular}{|c|c|c|c|}
\hline Author (Year) & Region/Countries & Study period & Causality \\
\hline \multicolumn{4}{|c|}{ Studies in favour of export-led growth [i.e. Exports Granger-cause economic growth] } \\
\hline Boame (1998) & Ghana & 1960 to 1992 & Exports $\rightarrow \mathrm{Y}$ \\
\hline $\begin{array}{l}\text { El-Sakka and Al- } \\
\text { Mutairi (2000) }\end{array}$ & Arab countries & 1970 to 1999 & $\begin{array}{l}\text { Exports } \rightarrow \text { Y (Iraq, Morocco, } \\
\text { Saudi Arabia and Syria) }\end{array}$ \\
\hline Fountas (2000) & Ireland & 1950 to 1990 & Exports $\rightarrow \mathrm{Y}$ \\
\hline Awokuse (2003) & Canada & $1961: 1$ to $2000: 4$ & Exports $\rightarrow \mathrm{Y}$ \\
\hline $\begin{array}{l}\text { Shirazi and Manap } \\
\text { (2004) }\end{array}$ & Pakistan & 1960 to 2003 & Exports $\rightarrow \mathrm{Y}$ \\
\hline \multirow[t]{5}{*}{$\begin{array}{l}\text { Shirazi and Manap } \\
\text { (2005) }\end{array}$} & \multirow[t]{5}{*}{ five South Asian countries } & $\begin{array}{l}\text { Pakistan: } 1960- \\
2003\end{array}$ & \multirow[t]{5}{*}{ Exports $\rightarrow \mathrm{Y}$ (Pakistan) } \\
\hline & & India: $1960-2002$ & \\
\hline & & $\begin{array}{l}\text { Bangladesh: 1973- } \\
2002\end{array}$ & \\
\hline & & $\begin{array}{l}\text { Sri Lanka: } 1960- \\
2002\end{array}$ & \\
\hline & & Nepal: 1975-2003 & \\
\hline $\begin{array}{l}\text { Siliverstovs and } \\
\text { Herzer (2006) }\end{array}$ & Chile & 1960 to 2001 & Exports $\rightarrow \mathrm{Y}$ \\
\hline $\begin{array}{l}\text { Jordaan and Eita } \\
\text { (2007) }\end{array}$ & Namibia & 1970 to 2005 & Exports $\rightarrow Y$ \\
\hline \multirow[t]{3}{*}{ Narayan et al. (2007) } & \multirow[t]{3}{*}{ Papua New Guinea and Fiji } & Papua New Guinea: & Exports $\rightarrow \mathrm{Y}$ \\
\hline & & $1961-1999$ & Fiji: Long-run \\
\hline & & Fiji: 1960-2001 & $\begin{array}{l}\text { Papua New Guinea: Short- } \\
\text { run }\end{array}$ \\
\hline Dash (2009) & India & $\begin{array}{l}\text { (1992[Q1 to } 2007 \\
\text { [Q4]) }\end{array}$ & Exports $\rightarrow \mathrm{Y}$ \\
\hline Rangasamy (2009) & South Africa & $1960 \mathrm{q} 1$ to $2007 \mathrm{q} 3$ & Exports $\rightarrow \mathrm{Y}$ \\
\hline Uddin et al. (2010) & Bhutan & 1980 to 2005 & Exports $\rightarrow \mathrm{Y}$ \\
\hline Ramona et al. (2010) & Romania & 1999 Q1 to 2009 Q4 & Exports $\rightarrow \mathrm{Y}$ \\
\hline Samad (2011) & Algeria & 1960 to 2005 & Exports $\rightarrow \mathrm{Y}$ \\
\hline Saad (2012) & Lebanon & 1970 to 2010 & Exports $\rightarrow \mathrm{Y}$ \\
\hline Tsaurai and & Zimbabwe & 1980 and 2010 & Exports $\rightarrow \mathrm{Y}$ \\
\hline \multicolumn{4}{|l|}{ Odhiambo (2012) } \\
\hline Dritsaki (2013) & Greece & 1960 to 2011 & Exports $\rightarrow Y$ \\
\hline Abdulkarim (2014) & Saudi Arabia & 1968 to 2011 & Exports $\rightarrow \mathrm{Y}$ \\
\hline Bilas et al. (2015) & Croatia & 1996 to 2012 & Exports $\rightarrow Y$ \\
\hline Ee (2016) & Selected SSA countries & 1985 to 2014 & Exports $\rightarrow \mathrm{Y}$ \\
\hline Ahmad et al. (2018) & ASEAN5 economies & 1981 to 2013 & Exports $\rightarrow \mathrm{Y}$ \\
\hline Ali and $\mathrm{Li}(2018)$ & China and Pakistan & 1980 to 2015 & Exports $\rightarrow \mathrm{Y}$ \\
\hline $\begin{array}{l}\text { Dinç and Gökmen } \\
\text { (2019) }\end{array}$ & Brazil & 1960 to 2017 & Exports $\rightarrow \mathrm{Y}$ (in the short run) \\
\hline \multicolumn{4}{|l|}{ Chamberlain (2020) } \\
\hline Kim et al. (2019) & Myanmar & 1981 to 2015 & Exports $\rightarrow \mathrm{Y}$ \\
\hline $\begin{array}{l}\text { Shakeel and Ahmed } \\
\text { (2020) }\end{array}$ & $\begin{array}{l}\text { A panel of five South Asian } \\
\text { countries }\end{array}$ & 1980 to 2014 & Exports $\rightarrow \mathrm{Y}$ (in the long run) \\
\hline
\end{tabular}

Table 1.

Previous empirical findings on the causal relationship between exports and economic growth in both developed and developing countries
B: Studies in favour of growth-led export [i.e. Economic growth Granger-causes exports]

$\begin{array}{llll}\text { Oxley (1993) } & \text { Portugal } & \text { 1865-1985 } & \text { Y } \rightarrow \text { Exports } \\ \text { Ahmad and Harnhirun } & \text { ASEAN Countries } & 1966 \text { through } 1988 & \text { Y } \rightarrow \text { Exports } \\ \text { (1996) } & & & \end{array}$

Henriques and

Sadorsky (1996)
Canada

1870 to 1991

$\mathrm{Y} \rightarrow$ Exports 


\begin{tabular}{|c|c|c|c|c|}
\hline Author (Year) & Region/Countries & Study period & Causality & \\
\hline $\begin{array}{l}\text { Baharumshah and } \\
\text { Rashid (1999) }\end{array}$ & Malaysia & $1970: 1$ to $1994: 4$ & $\mathrm{Y} \rightarrow$ Exports & growth in SSA \\
\hline $\begin{array}{l}\text { El-Sakka and Al- } \\
\text { Mutairi (2000) }\end{array}$ & Arab countries & 1970 to 1999 & $\mathrm{Y} \rightarrow$ Exports (the UAE) & \\
\hline $\begin{array}{l}\text { Hatemi-J and } \\
\text { Irandoust (2000) }\end{array}$ & Nordic economies & $\begin{array}{l}\text { Denmark: 1977.1- } \\
\text { 1996.1 } \\
\text { Finland: 1975.1- } \\
\text { 1994.4 } \\
\text { Norway: 1975.1- } \\
\text { 1996.1 } \\
\text { Sweden: 1980.1- } \\
1995.2\end{array}$ & $\begin{array}{l}\text { Y } \rightarrow \text { Exports (for the case of } \\
\text { Denmark) }\end{array}$ & 83 \\
\hline $\begin{array}{l}\text { Panas and Vamvoukas } \\
\text { (2002) }\end{array}$ & Greece & $1948-1997$ & $\mathrm{Y} \rightarrow$ Exports (in the long run) & \\
\hline Shan and Tian (2002) & Shanghai & $1990(1)$ to $1996(12)$ & $\mathrm{Y} \rightarrow$ Exports & \\
\hline $\begin{array}{l}\text { Reppas and } \\
\text { Christopoulos (2005) }\end{array}$ & $\begin{array}{l}\text { A sample of } 22 \text { less } \\
\text { developed Asian and } \\
\text { African countries }\end{array}$ & 1969 to 1999 & $\mathrm{Y} \rightarrow$ Exports & \\
\hline $\begin{array}{l}\text { Cetintas and Barisik } \\
\text { (2009) }\end{array}$ & 13 transition economies & $1995: 2$ to $2006: 4$ & $\mathrm{Y} \rightarrow$ Exports & \\
\hline Abbas (2012) & Pakistan & 1975 to 2010 & $\mathrm{Y} \rightarrow$ Exports & \\
\hline Igbal et al. (2012) & Pakistan & 1970 to 2009 & $\mathrm{Y} \rightarrow$ Exports & \\
\hline Shihab et al. (2014) & Jordan & 2000 to 2012 & $\mathrm{Y} \rightarrow$ Exports & \\
\hline Bonga et al. (2015) & Zimbabwe & 1975 to 2013 & $\mathrm{Y} \rightarrow$ Exports & \\
\hline $\begin{array}{l}\text { Gokmenoglu et al. } \\
\text { (2015) }\end{array}$ & Costa Rica & 1980 to 2013 & $\mathrm{Y} \rightarrow$ Exports & \\
\hline $\begin{array}{l}\text { Popovici and Călin } \\
\text { (2016) }\end{array}$ & Romania & $\begin{array}{l}\text { Quarterly data, } \\
2001 \text { to } 2015\end{array}$ & $\mathrm{Y} \rightarrow$ Exports & \\
\hline $\begin{array}{l}\text { Kalaitzi and Cleeve } \\
(2018)\end{array}$ & The UAE & $1981-2012$ & $\mathrm{Y} \rightarrow$ Exports (in the long run) & \\
\hline \multicolumn{5}{|c|}{$\begin{array}{l}\text { C: Studies in favour of bidirectional causality between exports and economic growth [i.e. exports and economic } \\
\text { growth Granger-cause each other] }\end{array}$} \\
\hline $\begin{array}{l}\text { Kwan and Cotsomitis } \\
\text { (1991) }\end{array}$ & China & 1952 to 1985 & $\begin{array}{l}\text { Exports } \leftrightarrow \mathrm{Y} \text { (for the period } \\
1952-1985)\end{array}$ & \\
\hline $\begin{array}{l}\text { Bahmani-Oskooee and } \\
\text { Janardhanan (1993) }\end{array}$ & LDCs & 1973I to $1988 \mathrm{IV}$ & $\begin{array}{l}\text { Exports } \leftrightarrow \text { Y (in almost all } \\
\text { countries in the sample) }\end{array}$ & \\
\hline Shan and Sun (1998) & China & 1987 to 1996 & Exports $\leftrightarrow \mathrm{Y}$ & \\
\hline $\begin{array}{l}\text { El-Sakka and Al- } \\
\text { Mutairi (2000) }\end{array}$ & Arab countries & 1970 to 1999 & $\begin{array}{l}\text { Exports ↔Y(Algeria, } \\
\text { Bahrain, Egypt, Jordan, } \\
\text { Mauritania and Oman }\end{array}$ & \\
\hline Wernerheim (2000) & Canada & 1947 to 96 & Exports $\leftrightarrow \mathrm{Y}$ & \\
\hline Abdulnasser (2002) & Japan & 1966:01 to $1999: 01$ & Exports $\leftrightarrow Y$ & \\
\hline $\begin{array}{l}\text { Hatemi-J and } \\
\text { Irandoust (2000) }\end{array}$ & Nordic economies & $\begin{array}{l}\text { Denmark: 1977.1- } \\
\text { 1996.1 } \\
\text { Finland: 1975.1- } \\
\text { 1994.4 } \\
\text { Norway: 1975.1- } \\
\text { 1996.1 } \\
\text { Sweden: 1980.1- } \\
\text { 1995.2 }\end{array}$ & $\begin{array}{l}\text { Exports } \leftrightarrow \mathrm{Y} \text { (for the case of } \\
\text { Finland, Norway and } \\
\text { Sweden) }\end{array}$ & \\
\hline Awokuse (2005) & Korea & 1963 to 2001 & Exports $\leftrightarrow Y$ & \\
\hline
\end{tabular}


EJMBE 31,1

\section{4}

\begin{tabular}{llll}
\hline Author (Year) & Region/Countries & Study period & Causality \\
\hline Shirazi and Manap & \multirow{2}{*}{ five South Asian countries } & Pakistan: 1960- & Exports ↔Y (Bangladesh \\
(2005) & & 2003 & and Nepal) \\
& & India: 1960-2002 &
\end{tabular}

Bangladesh: 1973-

2002

Sri Lanka: 1960-

2002

Nepal: 1975-2003

1996.1 to $2007.4 \quad$ Exports $\leftrightarrow \mathrm{Y}$

1980 to $2007 \quad$ Exports $\leftrightarrow \mathrm{Y}$

1978 to $2002 \quad$ Exports $\leftrightarrow \mathrm{Y}$

1971 to $2008 \quad$ Exports $\leftrightarrow \mathrm{Y}$

$\begin{array}{lll}\text { Libya } & 1980 \text { to } 2007 & \text { Exports } \leftrightarrow \text { Y } \\ \text { China } & 1978 \text { to } 2002 & \text { Exports } \leftrightarrow \text { Y } \\ \text { Indonesia } & 1971 \text { to } 2008 & \text { Exports } \leftrightarrow \text {Y }\end{array}$

Pakistan $\quad 1973$ to $2013 \quad$ Exports $\leftrightarrow \mathrm{Y}$

South Africa $\quad 1990$ to $2014 \quad$ Exports $\leftrightarrow Y$

India $\quad$ April 2005 to March $\quad$ Exports $\leftrightarrow \mathrm{Y}$

The UAE $\quad 1981-2012 \quad$ Exports $\leftrightarrow \mathrm{Y}$ (in the short run)

Brazil 1960-2017 Exports $\leftrightarrow \mathrm{Y}$ (in the long run)

A panel of five South Asian 1980 to $2014 \quad$ Exports $\leftrightarrow \mathrm{Y}$ (in the short run) countries

D: Studies in favour of neutrality hypothesis [i.e. No causality between exports and economic growth]

\section{Ahmad and Kwan \\ 1981 to 1987 \\ Exports $\neq \mathrm{Y}$}

(1991)

Jin and Yu (1996)

Abdulnasser and

Manucher (2000)

Ahmed et al. (2000)

El-Sakka and Al-

Mutairi (2000)

Tang (2006)

Shirazi and Manap

(2005)

Kalaitzi and

Chamberlain (2020)

The UAE

US economy

Greece, Ireland, Mexico,

Portugal and Turkey

Four South Asian

(Bangladesh, India,

Pakistan and Sri Lanka)

Arab countries

China

five South Asian countries
1959:1 to $1992: 3 \quad$ Exports $\neq \mathrm{Y}$

1960 to 1997

1970 to 1997

1970 to 1999

1970 to 2001

Pakistan:1960-

2003

India: 1960-2002

Bangladesh: 1973-

2002

Sri Lanka: 1960-

2002

Nepal: 1975-2003

1975 to 2012
Exports $\neq \mathrm{Y}$ (for Greece and Turkey)

Exports $\neq Y$ (for the case of Bangladesh, Pakistan and Sri Lanka)

Exports $\neq \mathrm{Y}$ (Kuwait, Libya, Qatar, Sudan and Tunis)

Exports $\neq Y$

Exports $\neq Y$ (Sri Lanka and India)

Note(s): Exports $\rightarrow$ Y means exports cause economic growth; $\mathrm{Y} \rightarrow$ Exports means economic growth causes

Table 1. exports; Exports $\leftrightarrow$ Y means there is bidirectional causality between exports and economic growth; and Exports $\neq Y$ means there is no causality between exports and economic growth 


\subsection{Data}

The data used in this study cover the period 1980 to 2017. The studied countries were divided into two panels where data were available - low-income panel and middle-income panel. The data were sourced from the World Bank's World Development Indicators. Although a number of proxies could be used to measure economic growth, in this study, real GDP per capita was used to measure the growth of the real sector. The advantage of using real GDP per capita is that it takes into consideration the effect of a population on economic growth. Some of the studies that have used this proxy include those of Shan et al. (2001), Thangavelu and James (2004), Rousseau and Vuthipadadorn (2005), Cooray (2010), Demirguc-Kunt et al. (2011), Odhiambo $(2014,2021)$, to mention a few. The exports variable is measured by the value of the exports of goods and services, while external debt, which has been used as an intermittent variable between exports and economic growth, is measured by the value of the external debt as a percentage of GNI.

\subsection{The panel unit root test}

In order to identify the order of integration of the variables used in the study, three panel unit root tests are employed: (1) Levin et al. (2002); (2) Im et al. (IPS) (2003); and (3) ADF Fischer tests. The results are reported in Table 2 for both low-income and middle-income countries.

The results of panel unit root tests reported in Table 2 show that the variables are consistently stationary in first difference.

\subsection{The panel cointegration test}

Having confirmed the order of integration of the variables used in this study, the next step is to examine the long-run relationship among these variables. For this purpose, two panel cointegration tests are employed in order to ensure the veracity of the findings. These are: (1) the Pedroni (2004) residual cointegration test; and (2) the Kao (1999) residual cointegration test. The cointegration results are reported in Table 3.

Overall, the results of the two panel cointegration tests reported in Table 3 reveal that the variables in the two models (1-2) are cointegrated; hence, the Granger-causality test could be performed.

\subsection{Trivariate Granger-causality results}

In this section, a dynamic multivariate panel Granger-causality model is employed to examine the causal relationship between exports, debt and economic growth in both low-

\begin{tabular}{|c|c|c|c|c|c|c|}
\hline & \multicolumn{2}{|c|}{ LLC $t$-Statistics } & \multicolumn{2}{|c|}{ IPS $W$-Statistics } & \multicolumn{2}{|c|}{ ADF - Fisher Chi-square } \\
\hline & Level & First difference & Level & First difference & Level & First difference \\
\hline \multicolumn{7}{|c|}{ Low-income SSA countries } \\
\hline EXP & -0.86612 & $-11.4343^{* * *}$ & -1.61785 & $-14.3055^{* * *}$ & 34.6601 & $102.194^{* * * *}$ \\
\hline$y / N$ & -2.06611 & $-6.28614^{* * *}$ & 1.26895 & $-11.7463^{* * * *}$ & 27.7939 & $126.990 * * *$ \\
\hline DEBT & -1.91001 & $-8.13716^{* * *}$ & -0.13487 & $-10.2718^{* * *}$ & 25.4644 & $77.5907^{* * * *}$ \\
\hline \multicolumn{7}{|c|}{ Middle-income SSA countries } \\
\hline EXP & -0.48707 & $-11.9829 * * *$ & -0.84128 & $-19.0471^{* * * *}$ & 45.3722 & $284.127 * * * *$ \\
\hline$y / N$ & 4.20445 & $-7.10078^{* * * *}$ & 0.80286 & $-13.0152^{* * * *}$ & 49.2910 & $219.670^{* * * *}$ \\
\hline DEBT & 0.80859 & $-8.53214 * * *$ & 1.11868 & $-15.2553^{* * * *}$ & 20.8375 & $235.867 * * *$ \\
\hline
\end{tabular}

Note(s): $* * *$ and $* * *$ indicate rejection of the respective null hypothesis at the $10 \%, 5 \%$ and $1 \%$ significance levels, respectively
Exports and economic growth in SSA 


\section{EJMBE 31,1}

Panel A: Low-income countries

Panel B: Middle-income

$t$-Statistic

Probability

$t$-Statistic $\quad$ Probability

Pedroni residual cointegration test

Pedroni panel cointegration test - within-dimension

\section{6}

$\begin{array}{lc}\text { Panel } v \text {-Statistic } & 14.28669 \\ \text { Panel rho-Statistic } & -3.458024 \\ \text { Panel PP-Statistic } & -0.192649 \\ \text { Panel ADF-Statistic } & -0.457711 \\ \text { edroni panel cointegration test }- \text { between-dimension } \\ \text { Group rho-Statistic } & -2.734473 \\ \text { Group PP-Statistic } & -4.279536 \\ \text { Group ADF-statistic } & -5.138824\end{array}$

Table 3.

Panel cointegration results

PANEL 2: Kao residual cointegration test

ADF $\quad-2.627023$

0.0000
0.0003
0.4236
0.3236
0.0031
0.0000
0.0000

2.838063

$-2.188797$

$-1.970811$

$-2.161709$

$-0.154009$

$-1.542654$

$-2.236847$

0.0043
0.0023

0.0143

0.0244

0.0153

0.4388

0.0615

0.0126

income and middle-income countries. The short-run causality is given by the $F$-statistics, which is expected to be statistically significant (see Asongu, 2014; Odhiambo, 2015). The long-run causality, on the other hand, is based on the coefficient of the error-correction term (ECT), which is expected to be negative and also statistically significant (see Odhiambo, 2021; Asongu et al., 2016). Table 4 presents the Granger-causality results for both low-income and middle-income countries.

Based on the findings reported in Panel A, it is clear that exports do not Granger-cause economic growth in low-income countries. This applies irrespective of whether the causality is estimated in the short run or in the long run. The short-run causality has been rejected by the corresponding $F$-statistic in the growth equation, which has been found to be statistically significant. Likewise, the long-run causality has been rejected by the coefficient of the error correction term in the economic growth in low-income countries' panel, which has also been found to be statistically insignificant. The same findings apply to the reverse causality from economic growth to exports. This can be confirmed by the corresponding F-statistic in the export's equation, which has been found to be statistically insignificant. This finding, therefore, shows that there is no causal relationship between exports and economic growth in either direction in low-income countries. This finding, though contrary to some of the previous studies, is consistent with previous studies, such as Ahmad and Kwan (1991) for the case of 47 African Countries, Ahmed et al. (2000) for the case of Bangladesh, Pakistan and Sri Lanka and Shirazi and Manap (2005) for Sri Lanka and India, among others.

In middle-income countries (Panel B), the results show that there is bidirectional causal relationship between exports and economic growth. This applies irrespective of whether the causality is conducted in the short run or in the long run. The causal flow from exports to economic growth has been confirmed by the coefficient of the ECM term and the corresponding $F$-statistic in Panel $\mathrm{B}$, which have been found to be both statistically significant. Likewise, the reverse causal flow from economic growth to exports has been confirmed by the coefficient of the ECT and the corresponding $F$-statistic in the export's equation, which have been found to be both statistically significant. Overall, the results of both low-income and middle-income countries show that the export-led growth paradigm, which gained prominence in the 1970s, may no longer be relevant to the countries under study. Other results show that for panel A, there is a long-run and short-run unidirectional causal flow from economic growth to debt in low-income countries. This is confirmed by the coefficient of the error correction term and the corresponding $F$-statistic in the debt equation, which have been found to be statistically significant. The results also show that for low- 


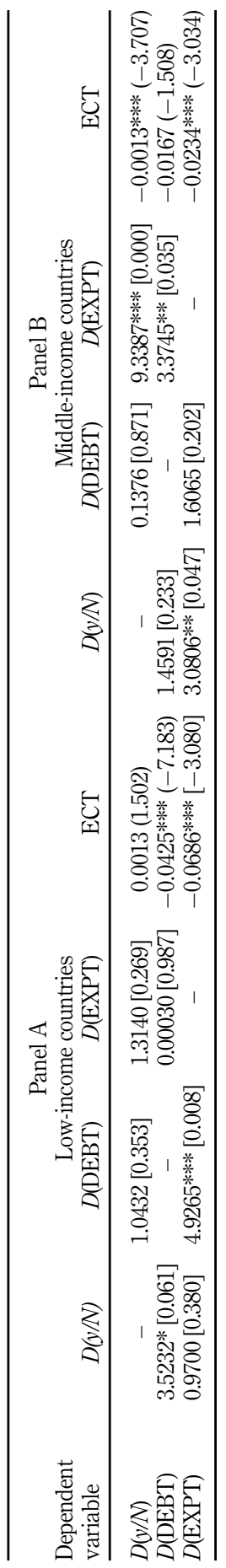

Exports and economic growth in SSA

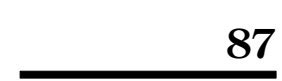

Table 4

Granger-causality results for all models 
EJMBE 31,1

income countries, there is a unidirectional causal flow from debt to exports both in the short run and in the long run. This finding is confirmed by the coefficient of the ECM and the corresponding $F$-statistic in the export's equation, which have been found to be both statistically significant. In Panel B, the results show that there is a short-run unidirectional causal flow from exports to debt. This has been confirmed by the corresponding $F$-statistic in the debt equation, which has been found to be statistically significant. However, no causality was found to exist between economic growth and debt in either direction. This applies irrespective of whether the causality was estimated in the short run or in the long run.

\section{Conclusion}

In this study, the dynamic causal relationship between exports and economic growth has been examined. The study was motivated by the current debate on the export-led growth versus growth-led export nexus. Unlike in some previous African studies, in the current study, SSA countries are divided into two groups, namely low-income and middle-income countries. In addition, external debt has been used as an intermittent variable in a bivariate setting between exports and economic growth, leading to a multivariate panel Grangercausality model. Using an ECM-based panel Granger-causality model, the study found that there is a long-run relationship between exports and economic growth in both groups of countries. However, the causality between these two variables varies significantly between low-income and middle-income countries. Specifically, the study found a short-run and longrun bidirectional causality between exports and economic growth to prevail in middle-income countries. However, in low-income countries, no causality was found to exist between these two variables in either direction. This applies irrespective of whether the causality was estimated in the short run or in the long run. These findings have important policy implications as they indicate that the causality between exports and economic growth in SSA countries varies with the countries' stage of development. The study, therefore, concludes that the argument that exports always Granger-cause economic growth may have been oversold to many SSA countries. This finding is not surprising given the nature and the composition of the exports of many SSA countries. Indeed, the exports of many SSA countries, especially low-income countries, are dominated by primary products, whose prices are relatively low when compared to those of manufactured goods. Moreover, given the fact that industrialisation in some SSA countries has been relatively slow, some SSA countries have been forced to continue importing some consumer goods that could be produced locally, thereby leading to widening current account deficits. Consistent with the contemporary literature, the study cautions low-income SSA countries against over-relying on an export-led growth strategy to achieve a sustained growth path as no causality between exports and economic growth has been found to exist in those countries. Instead, such countries should consider pursuing new growth strategies by building the domestic demand side of their economies alongside their export promotion strategies in order to expand the real sector of their economies. For middle-income countries, the results show that the expansion of exports through various exports promotion strategies has been an integral component of their economic growth path. Consequently, the study recommends that both export promotion strategies and pro-growth policies should be intensified as economic growth and exports have been found to reinforce each other in those countries.

\section{Notes}

1. See Sultanuzzaman et al. (2019).

2. See also Furuoka et al. (2019).

3. See Hsiao (2007). 


\section{References}

Abbas, S. (2012), "Causality between exports and economic growth: investigating suitable trade policy for Pakistan”, Eurasian Journal of Business and Economics, Vol. 5 No. 10, pp. 91-98.

Abdulkarim, K.A. (2014), "Exports, imports and economic growth in Saudi Arabia: an application of cointegration and error correction modeling", Pensee Journal, Vol. 76 No. 5.

Abdulnasser, H.-J. (2002), "Export performance and economic growth nexus in Japan: a bootstrap approach", Japan and the World Economy, Vol. 14 No. 1, pp. 25-33.

Abdulnasser, H.-J. and Manuchehr, I. (2000), “Time-series evidence for Balassa's export-led growth hypothesis", The Journal of International Trade and Economic Development, Vol. 9 No. 3 , pp. 355-365.

Ahmad, J. and Harnhirun, S. (1996), "Cointegration and causality between exports and economic growth: evidence from the ASEAN countries", The Canadian Journal of Economics, Vol. 29 No. 2, pp. S413-S416.

Ahmad, J. and Kwan, A.C.C. (1991), "Causality between exports and economic growth Empirical evidence from Africa", Economics Letters, Vol. 37 No. 3, pp. 243-248.

Ahmad, F., Draz, M.U. and Yang, S. (2018), "Causality nexus of exports, FDI and economic growth of the ASEAN5 economies: evidence from panel data analysis", The Journal of International Trade and Economic Development, Vol. 27 No. 6, pp. 685-700.

Ahmed, Q.Z., Butt, M.S., Alam, S. and Kazmi, A.A. (2000), "Economic growth, export, and external debt causality: the case of asian countries", The Pakistan Development Review, Vol. 39 No. 4 , pp. 591-608.

Ali, G. and Li, Z. (2018), "Exports-led growth or growth-led exports in the case of China and Pakistan: an empirical investigation from the ARDL and Granger causality approach", The International Trade Journal, Vol. 32 No. 3, pp. 293-314.

Asongu, S.A. (2014), "Linkages between investment flows and financial development: causality evidence from selected African countries", African Journal of Economic and Management Studies, Emerald Group Publishing, Vol. 5 No. 3, pp. 269-299.

Asongu, S.A., El Montasser, G. and Toumi, H. (2016), "Testing the relationships between energy consumption, $\mathrm{CO} 2$ emissions, and economic growth in 24 African countries: a panel ARDL approach”, Environmental Science and Pollution Research, Vol. 23 No. 7, pp. 6563-6573.

Awokuse, T.O. (2003), "Is the export-led growth hypothesis valid for Canada?", Canadian Journal of Economics, Vol. 36 No. 1, pp. 126-136.

Awokuse, T.O. (2005), "Exports, economic growth and causality in Korea", Applied Economics Letters, Vol. 12 No. 11, pp. 693-696.

Awokuse, T.O. and Christopoulos, D.K. (2009), "Nonlinear dynamics and the exports-output growth nexus", Economic Modelling, Vol. 26, pp. 184-190.

Baharumshah, A.Z. and Rashid, S. (1999), "Exports, imports and economic growth in Malaysia: empirical evidence based on multivariate time series", Asian Economic Journal, Vol. 13 No. 4, pp. 389-406.

Bahmani-Oskooee, M. (2009), "Export-led growth Vs. growth-led exports: LDCs experience", Journal of Developing Areas, Vol. 42 No. 2, pp. 179-212.

Bahmani-Oskooee, M. and Janardhanan, A. (1993), "Export growth and economic growth: an application of cointegration and error-correction modeling", The Journal of Developing Areas, Vol. 27 No. 4, pp. 535-542.

Balassa, B. (1978), "Exports and economic growth: further evidence", Journal of Development Economics, Vol. 5, pp. 181-89.

Ben-David, D. and Loewy, M.B. (1998), "Free-trade, growth, and convergence", Journal of Economic Growth, Vol. 3 No. 2, pp. 143-170.

Bhagwati, J. (1988), Protectionism, MIT Press, Cambridge, MA.

Exports and economic growth in SSA 
EJMBE 31,1

Bhagwati, J. and Srinivasan, T.N. (1975), Foreign Trade Regimes and Economic Development, National Bureau of Economic Research, Distributed by Columbia University Press, New York, NY.

Bilas, V., Bošnjak, M. and Franc, S. (2015), "Examining the export-led growth hypothesis: the case of Croatia”, Naše gospodarstvo/Our economy, Vol. 61 No. 3, pp. 22-31.

Blecker, R.A. (2002), "The balance-of-payments-constrained growth model and the limits to export-led growth", in Davidson, P. (Ed.), A Post Keynesian Perspective on Twenty-First Century Economic Problems, Edward Elgar, Cheltenham, UK and Northampton, pp. 69-88.

Blecker, R.A. (2003), "The diminishing returns to export-led growth", in Mead, W.R. and Schwenninger, S.R. (Eds), The Bridge to a Global Middle Class: Development, Trade, and International Finance, Kluwer, Boston, pp. 259-98.

Boame, A.K. (1998), "Primary-export-led growth: the evidence of Ghana", Journal of Economic Development, Vol. 23 No. 1, pp. 175-194.

Bonga, W.G., Shenje, T.E. and Sithole, R. (2015), "Export sector contribution to economic growth in Zimbabwe: a causality analysis", The International Journal of Business and Management, Vol. 3 No. 10 , pp. $452-464$.

Buffie, E. (1992), "On the condition for export-led growth", Canadian Journal of Economics, Vol. 25, pp. 211-225.

Cetintas, H. and Barisik, S. (2009), "Export, import and economic growth: the case of transition economies", Transition Studies Review, Vol. 15, pp. 636-649.

Cooray, A. (2010), "Do stock markets lead to economic growth?", Journal of Policy Modeling, Vol. 32 No. 4, pp. 448-460.

Dash, R.K. (2009), "Revisited export-led growth hypothesis: an empirical study on India", South Asia Economic Journal, Vol. 10, pp. 2305-324.

Demirguc-Kunt, A., Feyen, E. and Levine, R. (2011). "The evolving importance of banks and securities markets", World Bank Policy Research Working Paper, WPS 5805, World Bank Group, Washington, DC.

Dervis, K. (1979), "Foreign trade regimes and economic development: anatomy and consequences of exchange control regimes: Jagdish N. Bhagwati national bureau of economic research (ballinger publishing company, Cambridge, MA, 1978) pp. xix + 232", Journal of Development Economics, Vol. 6 No. 3, pp. 447-451.

Dinç, D.T. and Gökmen, A. (2019), "Export-led economic growth and the case of Brazil: an empirical research", Journal of Transnational Management, Vol. 24 No. 2, pp. 122-141.

Dritsaki, C. (2013), "Causal nexus between economic growth, exports and government debt: the case of Greece", Procedia Economics and Finance, Vol. 5, pp. 251-259.

Ee, C.Y. (2016), "Export-led growth hypothesis: empirical evidence from selected sub-saharan african countries", Procedia Economics and Finance, Vol. 35, pp. 232-240.

El-Sakka, M.I. and Al-Mutairi, N.H. (2000), "Exports and economic growth: the Arab experience", Pakistan Development Review, Vol. 39 No. 2, pp. 153-169.

Elbeydi, K.R.M., Hamuda, A.M. and Gazda, V. (2010), "The relationship between export and economic growth in Libya Arab Jamahiriya", Theoretical and Applied Economics, Vol. 17 Nos 1(542), pp. 69-76.

Felipe, J. (2003), “Is export-led growth passe? Implications for developing Asia”, Working Paper No 48, Asian Development Bank, Manila.

Findlay, R. (1984), "Growth and development in trade models", in Jones, R. and Kenen, P. (Eds), Handbook of International Economics, North-Holland, Amsterdam, Vol. 1.

Fountas, S. (2000), "Some evidence on the export-led growth hypothesis for Ireland", Applied Economics Letters, Vol. 7 No. 4, pp. 211-214.

Furuoka, F., Harvey, H. and Munir, Q. (2019), "Export diversification, mean-reversion of exports, and stability of export-growth causality”, The International Trade Journal, Vol. 33 No. 3, pp. 221-238. 
Giles, J.A. and Williams, C.L. (2000), "Export-led growth: a survey of the empirical literature and some noncausality results Part 11", Econometrics Working Paper EWP0001, University of Victoria, Victoria.

Gokmenoglu, K.K., Sehnaz, Z. and Taspinar, N. (2015), "The export-led growth: a case study of Costa Rica”, Procedia Economics and Finance, Vol. 25, pp. 71-477.

Guntukula, R. (2018), "Exports, imports and economic growth in India: evidence from cointegration and causality analysis", Theoretical and Applied Economics, Vol. 20 No. 2(615), pp. 221-230, summer.

Hart, O. (1983), "The market mechanism as an incentive scheme”, Bell Journal of Economics, Vol. 14,

Exports and economic growth in SSA pp. 366-382.

Hatemi-J, A. and Irandoust, M. (2000), "Export performance and economic growth causality: an empirical analysis", Atlantic Economic Journal, Vol. 28, pp. 412-426.

Henriques, I. and Sadorsky, P. (1996), "Export-led growth or growth-driven exports? The Canadian case", The Canadian Journal of Economics, Vol. 29 No. 3, pp. 540-555.

Hsiao, C. (2003), Analysis of Panel Data, Cambridge University Press, Cambridge.

Hsiao, C. (2007), "Panel data analysis—advantages and challenges", TEST, Vol. 16, pp. 1-22.

Hsiao, C., Mountain, D.C., Chan, M.W.L. and Tsui, K.Y. (1989), "Modeling ontario regional electricity system demand using a mixed fixed and random coefficients approach", Regional Science and Urban Economics, Vol. 19, pp. 567-587.

Hsiao, C., Appelbe, T.W. and Dineen, C.R. (1993), "A general framework for panel data analysis - with an application to Canadian customer dialed long distance service", Journal of Econometrics, Vol. 59, pp. 63-86.

Hsiao, C., Mountain, D.C. and Ho-Illman, K. (1995), "Bayesian integration of EndUse metering and conditional demand analysis", Journal of Business and Economic Statistics, Vol. 13, pp. 315-326.

Igbal, A., Hameed, I. and Devi, K. (2012), "Relationship between exports and economic growth of Pakistan”, European Journal of Social Sciences, Vol. 32 No. 3, pp. 453-460.

Im, K.S., Pesaran, H.M. and Shin, Y. (2003), "Testing for unit roots in heterogeneous panels”, Journal of Econometrics, Vol. 115 No. 1, pp. 53-74.

Jin, J.C. and Yu, E.S.H. (1996), "Export-led growth and the US economy: another look", Applied Economics Letters, Vol. 3 No. 5, pp. 341-344.

Jordaan, A.C. and Eita, J.H. (2007), "Export and economic growth in Namibia: a granger causality analysis", South African Journal of Economics, Vol. 75 No. 3, pp. 540-547.

Jordaan, A.C. and Eita, J.H. (2009), "Testing the export-led growth hypothesis for Botswana: a causality analysis", BOJE: Botswana Journal of Economics, Vol. 6 No. 10, pp. 2-14.

Kalaitzi, A.S. and Chamberlain, T.W. (2020), "Merchandise exports and economic growth: multivariate time series analysis for the United Arab Emirates", Journal of Applied Economics, Vol. 23 No. 1, pp. 163-182.

Kalaitzi, A.S. and Cleeve, E. (2018), "Export-led growth in the UAE: multivariate causality between primary exports, manufactured exports and economic growth", Eurasian Business Review, Vol. 8, pp. 341-365.

Kao, C. (1999), "Spurious regression and residual-based tests for cointegration in panel data", Journal of Econometrics, Vol. 90 No. 1, pp. 1-44.

Keesing, D.B. (1967), "Outward-looking policies and economic development", The Economic Journal, Vol. 77 No. 306, pp. 303-320.

Kim, B., Kyophilavong, P., Nozaki, K. and Charoenrat, T. (2019), "Does the export-led growth hypothesis hold for Myanmar?", Global Business Review, pp. 1-13, doi: 10.1177/ 0972150919863929.

Kwan, A.C. and Cotsomitis, J.A. (1991), "Economic growth and the expanding export sector: China 1952-1985”, International Economic Journal, Vol. 5 No. 1, pp. 105-116. 
EJMBE 31,1

Lee, C.H. and Huang, B.N. (2002), "The relationship between exports and economic growth in east asian countries: a multivariate threshold autoregressive approach", Journal of Economic Development, Vol. 27, pp. 45-68.

Levin, A., Lin, C.F. and Chu, C.-S.J. (2002), "Unit root tests in panel data: asymptotic and finite sample properties", Journal of Econometrics, Vol. 108 No. 1, pp. 1-24.

Mahadevan, R. (2007), "New evidence on the export-led growth nexus: a case study of Malaysia", The World Economy, Vol. 30 No. 7, pp. 1069-1083.

McKinnon, R. (1964), "Foreign exchange constraint in economic development and efficient aid allocation”, Economic Journal, Vol. 74, pp. 338-409.

Narayan, P.K., Narayan, S., Prasad, B.C. and Prasad, A. (2007), "Export-led growth hypothesis: evidence from Papua New Guinea and Fiji”, Journal of Economic Studies, Vol. 34 No. 4, pp. 341-351.

Odhiambo, N.M. (2014), "Energy dependence in developing countries: does the level of income matter?", Atlantic Economic Journal, Vol. 42 No. 1, pp. 65-77.

Odhiambo, N.M. (2015), "Government expenditure and economic growth in South Africa: an empirical investigation”, Atlantic Economic Journal, Vol. 43 No. 3, pp. 393-406.

Odhiambo (2021), "Energy consumption and economic growth in Botswana: empirical evidence from A disaggregated data", International Review of Applied Economics, Vol. 35 No. 1, pp. 3-24.

Oxley, L. (1993), “Cointegration, causality and export-led growth in Portugal, 1865-1985”, Economics Letters, Vol. 43, pp. 163-166.

Palley, T.I. (2011), “The contradictions of export-led growth", Public Policy Brief, No. 119, ISBN: 9781-936192-17-5, Levy Economics Institute of Bard College, Annandale-on-Hudson, New York, NY.

Panas, E. and Vamvoukas, G. (2002), "Further evidence on the export-led growth hypothesis", Applied Economics Letters, Taylor and Francis Journals, Vol. 9 No. 11, pp. 731-735.

Pedroni, P. (2004), "Panel cointegration: asymptotic and finite sample properties of pooled time series tests with an application to the PPP hypothesis", Econometric Theory, Vol. 20 No. 3, pp. 597-325.

Popovici, O.C. and Călin, A.C. (2016), "Economic growth, foreign investments and exports in Romania: a VECM analysis", The Romanian Economic Journal, Vol. 61, pp. 95-122.

Rahmaddi, R. and Ichihashi, M. (2011), "Exports and economic growth in Indonesia: a causality approach based on multi-variate error correction model", Journal of International Development and Cooperation, Vol. 17 No. 2, pp. 53-73.

Ramona, D., Razvan, S. and Costel, N. (2010), "Exports as an engine for the economic growth: the case of Romania", Vanguard Scientific Instruments in Management No. 2, pp. 303-308, February 2011.

Rangasamy, L. (2009), "Exports and economic growth: the case of South Africa", Journal of International Development, Vol. 21, pp. 603-617.

Reppas, P. and Christopoulos, D. (2005), "The export-output growth nexus: evidence from African and Asian countries", Journal of Policy Modeling, Vol. 27, pp. 929-940.

Rousseau, P.L. and Vuthipadadorn, D. (2005), "Finance, investment, and growth: time series evidence from 10 asian economies", Journal of Macroeconomics, Vol. 27, pp. 87-106.

Saad, W. (2012), "Causality between economic growth, export, and external debt servicing: the case of Lebanon", International Journal of Economics and Finance, Vol. 4 No. 11, pp. 134-143.

Saleem, A. and Sial, M.H. (2015), "Exports-growth nexus in Pakistan: cointegration and causality analysis", Pakistan Economic and Social Review, Vol. 53 No. 1, pp. 17-46.

Salim, R.A. and Hossain, M.A. (2011), "The linkage between export and income: further evidence from Bangladesh”, Singapore Economic Review, Vol. 56, pp. 79-95.

Samad, A. (2011), "Exploring exports and economic growth causality in Algeria", Journal of Economics and Behavioral Studies, Vol. 2 No. 3, pp. 92-96. 
Shakeel, M. and Ahmed, A. (2020), "Economic growth, exports, and role of energy conservation: evidence from panel co-integration-based causality models in South Asia”, Energy and Environment, Vol. 32 No. 1, pp. 3-24, doi: 10.1177/0958305X19899372.

Shan, J. and Sun, F. (1998), "On the export-led growth hypothesis: the econometric evidence from China”, Applied Economics, Vol. 30 No. 8, pp. 1055-1065.

Shan, J. and Tian, G.G. (2002), "Causality between exports and economic growth: the empirical evidence from Shanghai", Australian Economic Papers, Vol. 37 No. 2, pp. 195-202.

Shan, J.Z., Morris, A.G. and Sun, F. (2001), "Financial development and economic growth: an egg-andchicken problem?", Review of International Economics, Vol. 9 No. 3, pp. 443-454.

Shihab, R.A., Soufan, T. and Abdul- Khaliq, S. (2014), "The causal relationship between exports and economic growth in Jordan”, Global Journal of Management and Business Research: B Economics and Commerce, Vol. 14 No. 1, pp. 119-124.

Shirazi, N.S. and Manap, T.A.A. (2004), "Export and economic growth nexus: the case of Pakistan", Pakistan Development Review, Vol. 43 No. 4 (part II), pp. 563-581.

Shirazi, N.S. and Manap, T.A. (2005), "Export-led growth hypothesis: further econometric evidence from South Asia", The Developing Economies, Vol. 43 No. 4, pp. 472-488.

Siliverstovs, B. and Herzer, D. (2006), "Export-led growth hypothesis: evidence for Chile", Applied Economics Letters, Vol. 13 No. 5, pp. 319-324.

Sultanuzzaman, M.R., Fan, H., Mohamued, E.A., Hossain, M.I. and Islam, M.A. (2019), "Effects of export and technology on economic growth: selected emerging Asian economies", Economic Research-Ekonomska Istraživanja, Vol. 32 No. 1, pp. 2515-2531.

Sunde, T. (2017), "Foreign direct investment, exports and economic growth: ADRL and causality analysis for South Africa", Research in International Business and Finance, Vol. 41, pp. 434-444.

Tang, T.C. (2006), "New evidence on export expansion, economic growth and causality in China", Applied Economics Letters, Vol. 13 No. 12, pp. 801-803.

Tanga, C.F., Lai, Y.W. and Ozturk, I. (2015), "How stable is the export-led growth hypothesis? Evidence from Asia's Four Little Dragons", Economic Modelling, Vol. 44, pp. 229-235.

Thangavelu, S.M. and James, A.B.J. (2004), "Financial development and economic growth in Australia: an empirical analysis", Empirical Economics, Vol. 29, pp. 247-260.

Tsaurai, K. and Odhiambo, N.M. (2012), "A dynamic causality test of exports and economic growth in Zimbabwe", International Journal of Economic Policy in Emerging Economies, Vol. 5 No. 3, pp. 231-242.

Tsen, W.H. (2010), "Exports, domestic demand, and economic growth in China: granger causality analysis", Review of Development Economics, Vol. 14 No. 3, pp. 625-639.

Uddin, M.G.S., Khan, S.A. and Alam, M.M. (2010), "An empirical study on export, import and economic growth in Bhutan", Indian Development Review, Vol. 8 No. 1, pp. 95-104.

Wernerheim, C. and Micheal (2000), "Cointegration and causality in the exports-GDP nexus: the postwar evidence for Canada”, Empirical Economics, Vol. 25, pp. 111-125.

World Bank (1987), World Development Report 1987, Oxford University Press, New York, NY.

\section{Corresponding author}

Nicholas M. Odhiambo can be contacted at: odhianm@unisa.ac.za and nmbaya99@yahoo.com

For instructions on how to order reprints of this article, please visit our website:

www.emeraldgrouppublishing.com/licensing/reprints.htm

Or contact us for further details: permissions@emeraldinsight.com 